\title{
КОРИГУВАННЯ СПЕКТРІВ ВИПРОМІНЕННЯ СВІТЛОДІОДНИХ ОСВІТЛЮВАЛЬНИХ УСТАНОВОК ДЛЯ ПІДВИЩЕННЯ ЇХ ФОТОБІОЛОГІЧНОЇ БЕЗПЕЧНОСТІ
}

\author{
О. С. Пітяков, Аспірант Харківського начіонального університету міського господарства \\ ім. О.М. Бекетова, директор відокремленого структурного підрозділу: «Полтавський \\ політехнічний фаховий коледж Начіонального технічного університету «Харківський \\ політехнічний інститут», м. Полтава, Украӥна,
}

ORCID ID: http://orcid.org/0000-0001-9306-4246

П. І. Неєжмаков, Доктор технічних наук, професор, генеральний директор Наиіонального наукового иентру «Інститут метрологї̈, м. Харків, Україна,

ORCID ID: http://orcid.org/0000-0002-5727-6089

C. В. Шпак, Кандидат технічних наук, науковий співробітник Державного підприємства «Полтавський регіональний науково-технічний центр стандартизації, метрології та сертифікаиї̈, м. Полтава, Україна, ORCID ID: http://orcid.org/0000-0002-1417-3944

С. Г. Кислиця, Кандидат технічних наук, доцент Наџіонального університету «Полтавська політехніка імені Юрія Кондратюка», м. Полтава, Україна,

ORCID ID: https://orcid.org/0000-0002-2431-9900

Г. М. Кожушко, Доктор технічних наук, професор Національного університету «Полтавська політехніка імені Юрія Кондратюка», м. Полтава, Україна,

ORCID ID: http://orcid.org/0000-0002-7306-4529

\section{DOI: https://doi.org/10.31435/rsglobal_conf/30062021/7628}

\begin{abstract}
The paper considers the issues of increasing the photobiological safety of LED lamps by adjusting the spectrum, which allows to fulfill the conditions of "melanopsin cross", the essence of which is that the radiation intensity at a wavelength of $480 \mathrm{~nm}$ should always be greater than the intensity at $460 \mathrm{~nm}$ and $450 \mathrm{~nm}$. These conditions are met for a black body, but are not met at any correlated temperature (CCT) for LEDs emitting bands of blue and yellow-green light. In LEDs, one of the maxima of radiation is about $450 \mathrm{~nm}$ and coincides with the maximum of the weight function of the dangerous action of blue light, and the minimum - at $480 \mathrm{~nm}$ - the region of the spectrum that most effectively generates a signal to narrow the pupil. From the point of view of increasing photobiological safety, the maximum at $450 \mathrm{~nm}$ must be reduced, and the "failure" at $480 \mathrm{~nm}$ (for effective pupil narrowing) must be filled to a level exceeding the level at $450 \mathrm{~nm}$. In order to achieve the "melanopsin cross" methods were proposed to adjust the spectral composition of the light environment, forming LED lighting installations, by additional use of light sources with a radiation spectrum that complements the spectrum of LED lamps in the region of $480 \mathrm{~nm}$, and limiting the radiation intensity of 450 lamps $n m$ by using selectively absorbing and permeable materials.
\end{abstract}

Keywords: LED lamp, photobiological danger, blue light, radiation spectrum, "melanopsin cross".

Вступ. Фотобіологічному впливу світла на здоров'я людей присвячена велика кількість сучасних досліджень [1-6]. CIE в [7] надано роз'яснення стосовно терміну «небезпека синього світла». Він має застосовуватись тільки при розгляді фотохімічного ризику пошкодження сітківки ока (фотомакулопатії), зазвичай пов'язаної з фіксацією погляду на яскраві джерела світла. Ризик фотохімічного пошкодження сітківки ока синім світлом залежить від довжини хвилі (з максимумом близько 435 - 440 нм). Міжнародна комісія з захисту від неіонізуючого випромінення (ICNIRP) опублікувала функцію вагомості небезпеки синього світла [8], яка тепер стандартизована в міжнародному стандарті IEC 62471 «Фотобіологічна безпека ламп i лампових систем» [9].

Теорія ризиків негативного впливу світла і методологія розрахунку фотобіологічної безпеки була розроблена на базі основоположних статей $[1,10] .3$ точки зору визначення надлишкової дози синього світла представляє зацікавленість робота [11]. В цьому 
європейському звіті «Оптична безпека світлодіодного освітлення» у відповідності з вимогами міжнародного стандарту IEC 62471проведено порівняння спектрів сонячного світла зі світлом штучних джерел світла (з метою визначення надлишкової долі синього світла в спектрі світлодіодів). На рис. 1 представлено спектр світлодіодів в яких кристал, що випромінює синє світло, покритий жовтим люмінофором для отримання білого світла. На цьому ж рисунку наведено спектр випромінення чорного тіла і лампи розжарювання, а також показані точки, на які необхідно звертати увагу при аналізі спектру будь-якого джерела. В інтервалі колірних температур від 4000 К до 6500 К виконуються умови «меланопсинового хреста» при яких на енергетичному спектрі світла амплітуда для 480 нм повинна бути завжди вищою за амплітуду в інтервалі довжин хвиль 450-460 нм.

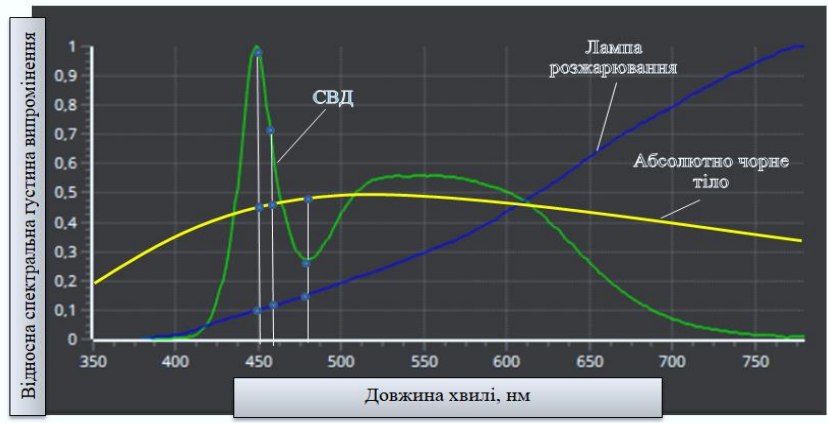

Рис. 1. Відносний розподіл спектральної густини для чорного тіла, лампи розжарювання та світлодіода

Порівнюючи спектр сонячного світла i світлодіодів наводяться наступні дані: світлодіодна лампа (CСТ=4200 К) має відносну амплітуду на 450 нм вищу, ніж у сонячного світла з ССТ 6500 К; в спектрі світлодіодної лампи з ССТ 4200 К провал на довжині хвилі 480 нм на порядок більше, ніж в спектрі сонячного світла з ССТ 6500 К; в спектрі світлодіодної лампи 3 ССТ 4200 К провал на 480 нм в рази більший, ніж в спектрі лампи розжарювання з ССТ $2700 \mathrm{~K}$.

3 цього слідує, що доза синього світла (довжина хвилі 450 нм) в спектрі світлодіодної лампи (світильника) 3 ССТ $4200 \mathrm{~K}$ при однаковому рівні освітленості буде значно перевищувати (на $40 \%$ ) дозу синього світла в спектрі сонця. Ця різниця і $є$ надлишковою дозою (при однакових ССТ та рівнях освітленості). Але слід також враховувати, що доза буде збільшена за рахунок неадекватного управління розмірами зіниць, які залежать від амплітуди на довжині хвилі 480 нм.

В [12] зроблені висновки про те, що світло $з$ довжиною хвилі 450-460 нм спричиняє окислювальний стрес сітківки а світло з 460 нм і 480 нм - через меланопсин гангліозних клітин управляє, відповідно, гормональною системою та діаметрам зіниці. При світлодіодному освітленні білими світлодіодами (синє світло кристала і жовте світло люмінофора), які мають провал в спектрі на 480 нм, відбувається неадекватне регулювання розміру зіниці. Адекватне регулювання діаметра зіниці відбувається при умові $\mathrm{I}_{450}$ нм $\leq \mathrm{I}_{480}$ нм, де $\mathrm{I}_{450}$ нм - амплітуда яскравості при 450 нм; $\mathrm{I}_{480}$ нм - амплітуда яскравості при 480 нм. Таке співвідношення яскравостей у сонячного світла і ламп розжарювання. Рівень фотохімічного ризику для очей від синього світла залежить від накопиченої дози, яка створюється як при високій яскравості протягом короткочасної експозиції, так і в результаті низько інтенсивного впливу протягом тривалого часу. При цьому особливому ризику піддаються такі групи, як діти, літні люди та працівники, діяльність яких проходить в умовах високого рівня освітленості джерелами світла 3 високою корельовано колірною температурою, тому дослідження факторів, що впливають на фотобіологічну безпечність світлодіодних ламп та світильників $\epsilon$ актуальною задачею.

Підвищення фотобіологічної безпечності синього світла можна досягти шляхом зменшення енергетичної яскравості в синій області спектра та зміною спектрального складу випромінення в цій області. Зниження яскравості $є$ фактором, що впливає переважно на фотобіологічну безпечність при прямому спогляданні на яскраве джерело протягом обмеженого часу i вирішується шляхом застосування різних розсіювачів світла. Зміна спектрального складу впливає на безпечність як при прямому спогляданні на яскраве світло, 
так і при обмеженні доз опромінення від розсіюваного світла протягом тривалого часу. Суттєвих змін спектрального складу випромінювання сучасних світлодіодів, що масово використовуються при виробництві світлодіодних ламп та світильників, які б задовольняли вимогам «меланопсинового хреста» досягти неможливо без застосування кристалів i люмінофорів 3 іншими параметрами випромінення в областях спектру 450 нм, 460 нм та 480 нм. Такі розробки ведуться в [13], але на сьогодні вони ще не мають комерційного застосування. В таблиці 1 та на рис. 2 наведені дані фотометричних та спектральних вимірювань дослідного зразка лампи Soraa PAR38 [13].

Таблиця 1. Результати експериментальних вимірювань лампи Soraa PAR38

\begin{tabular}{|l|c|}
\hline Фотометричні, колориметричні та електричні параметри & Дані вимірювань \\
\hline - $\quad$ світловий потік, лм & 1044 \\
- світлова віддача, лм/Вт & 58 \\
- корельована колірна температура (ССТ), K & 3015 \\
- загальний індекс кольоропередачі, $\mathrm{R}_{\text {a }}$ відн. одиниць & $95-96$ \\
- потужність, Вт & 18 \\
\hline
\end{tabular}

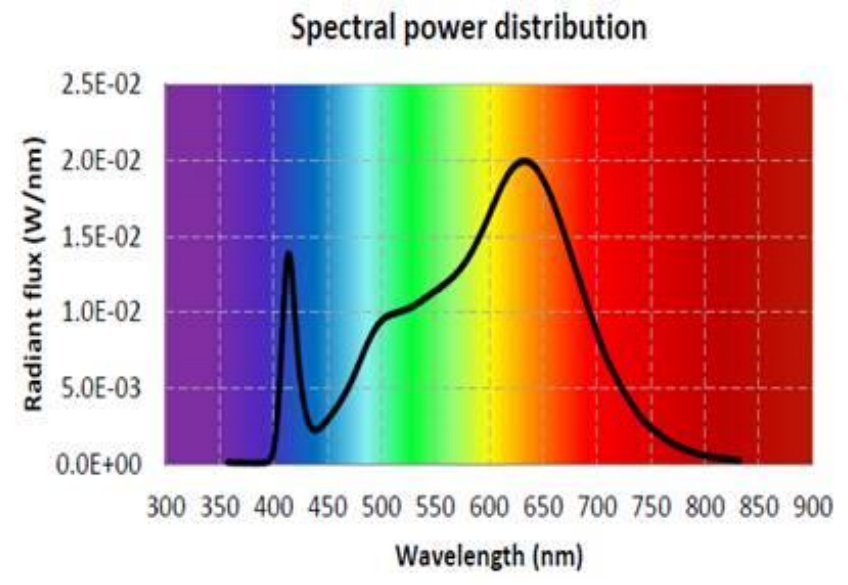

Puc. 2. Спектр випромінювання лампи Sогаa PAR38 [13]

Аналізуючи ці дані слід відзначити, що світлова віддача дослідного зразка лампи, в порівнянні з лампами, в яких використовуються світлодіоди з синьо-жовтим світлом, значно нижча, досить низька також і ССТ. Основні переваги лампи: високий загальний індекс кольоропередачі і відповідність спектру вимогам «меланопсинового хреста».

Для зміни спектрального складу розсіюваного світла, який впливає при тривалій експозиції на надлишкову дозу синього світла, то тут, крім вище згаданого, існує кілька варіантів: одночасне застосування джерел світла 3 різним спектральним складом для покращення співвідношення між спектральною густиною при 480 нм та 450 нм (наприклад, для загального освітлення застосовувати світлодіодні світильники з ССТ $3000 \mathrm{~K}-4000 \mathrm{~K}$, а для місцевого - світильники з галогенними лампами розжарювання з ССТ 2900 К); застосовувати в лампах та світильниках селективні фільтри, які обмежують яскравість випромінення в області 450 нм; використовувати у світлодіодних світильниках внутрішнє відбиваюче покриття 3 коефіцієнтом відбиття в області спектру 450 нм меншим, ніж в області 480 нм; використовувати для фарбування стелі та стін приміщень матеріали, у яких коефіцієнт відбиття в області спектру з максимумом при 450 нм є меншим, ніж в області 480 нм.

Метою даної роботи $є$ дослідження цих методів коригування спектрів випромінення світлодіодних світильників для забезпечення умов «меланопсинового хреста» і зменшення утворення надлишкової дози синього світла. Суть умов «меланопсинового хреста» полягає в тому, що рівень випромінення при довжині хвилі 480 нм має бути завжди більшим за рівень при довжині хвилі 450 нм.

В роботі наведені результати дослідження впливу розсіювачів на яскравість світла та корегування спектру в області 450 нм - 480 нм за рахунок одночасного використання ламп та 
світильників з різним спектральним складом, селективно пропускаючих та відбиваючих світломатеріалів.

Методи та результати дослідження. Спектри випромінення світильників вимірювали 3 використанням спектрорадіометра MK350S. На основі виміряних значень спектральної густини випромінення 3 використанням програмного забезпечення MK350S розраховувались фотометричні (освітленість) та колориметричні (ССТ) параметри. Невизначеності вимірювань були в межах бюджету невизначеностей, рекомендованого європейським стандартом [14]. Для ССТ калібрована стандартна невизначеність становила $30 \mathrm{~K}$, а загальна розширена невизначеність $(\kappa=2)-60$ К. Спектри пропускання фільтрів та відбиття непрозорих матеріалів вимірювали з використанням спектрофотометру $\chi 950$.

Сучасні світлодіодні лампи і світильники, в яких використовуються світлодіоди 3 кристалами, що випромінюють синє світло (частина якого для отримання білого світла поглинається люмінофором, що випромінює жовте світло) мають максимум випромінення в області 450 нм і мінімум в області 480 нм. Максимум при 450 нм співпадає 3 максимумом небезпечності дії синього світла, а при довжині хвилі 480 нм найбільш ефективно формується сигнал для звуження зіниці ока. Між цими областями, при $\lambda=460$ нм, синє світло максимально поглинається жовтою плямою сітківки, яка захищає іiі від його негативної дії. На рисунку 1 наведено спектр випромінювання світлодіода і вказані точки, на які необхідно звернути увагу для підвищення фотобіологічної безпечності синього світла. Для порівняння на рисунку наведені спектри випромінення чорного тіла при $\mathrm{CCT}=6000 \mathrm{~K}$ та лампи розжарювання. 3 точки зору підвищення фотобіологічної безпечності синього світла максимум при 450 нм необхідно зменшувати, а «провал» в області 480 нм, для ефективного звуження зіниці, потрібно заповнити. Для спектрального складу випромінення джерела світла загального освітлення мають виконуватись умови «меланопсинового хреста», суть яких полягає в тому, що спектральна густина випромінення при $\lambda=480$ нм має бути завжди більшою за густину при

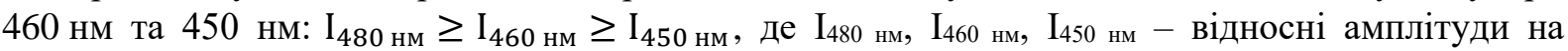
графіку спектрального розподілу при 480 нм, 460 нм та 450 нм.

Як видно з рис. 1 умови «меланопсинового хреста» виконуються для чорного тіла і для ламп розжарювання. В світлодіодних джерелах світла в спектральному діапазоні $з$ максимумом при 450 нм є відносний надлишок синього світла в порівнянні 3 сонячним та лампами розжарювання. Ця різниця і складає надлишкову дозу синього світла відносно сонячного (при однакових рівнях освітленості та ССТ). Доза доповнюється також за рахунок більшого розміру зіниці, що має місце при освітленні світлодіодними джерелами 3 «провалом» в області спектру 480 нм. Саме сумарна надлишкова доза синього світла і призводить до прискорення деградаційних процесів, які збільшують ризик погіршення зору в порівнянні з сонячним світлом (при однакових рівнях освітленості, ССТ і ефективного захисту сітківки жовтою плямою).

Один із шляхів забезпечення умов «меланопсинового хреста» $\epsilon$ використання в освітлювальних установках, крім світлодіодних світильників та ламп, лампи та світильники в яких ці умови виконуються, наприклад галогенних ламп розжарювання (ГЛР). В таблиці 2 та на рис. 3 наведені результати вимірювання світлотехнічних та спектральних характеристик освітлювальних установок зі світлодіодними світильниками для загального освітлення та світильниками 3 ГЛР для місцевого освітлення. ССТ світлодіодних світильників не перевищувала $3500 \mathrm{~K}$.

Таблиця 2. Результати вимірювання параметрів освітлювальних установок 3 світлодіодними світильниками та світильниками з ГЛР

\begin{tabular}{|c|c|c|c|c|c|c|c|}
\hline 志㽦 & 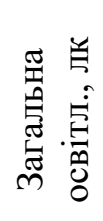 & 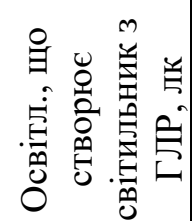 & 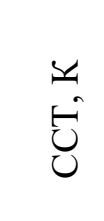 & $\tilde{2}$ & 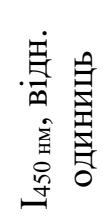 & 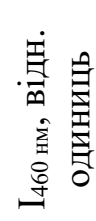 & 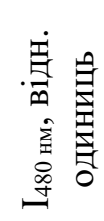 \\
\hline Загальне освітлення & 292 & - & 2948 & 81,8 & 3,89 & 3,55 & 2,17 \\
\hline Місцеве освітлення & - & 248 & 2909 & 98,7 & 1,35 & 1,58 & 3,03 \\
\hline Сумарний результат & & 540 & 2800 & 91,7 & 5,24 & 5,13 & 5,20 \\
\hline
\end{tabular}




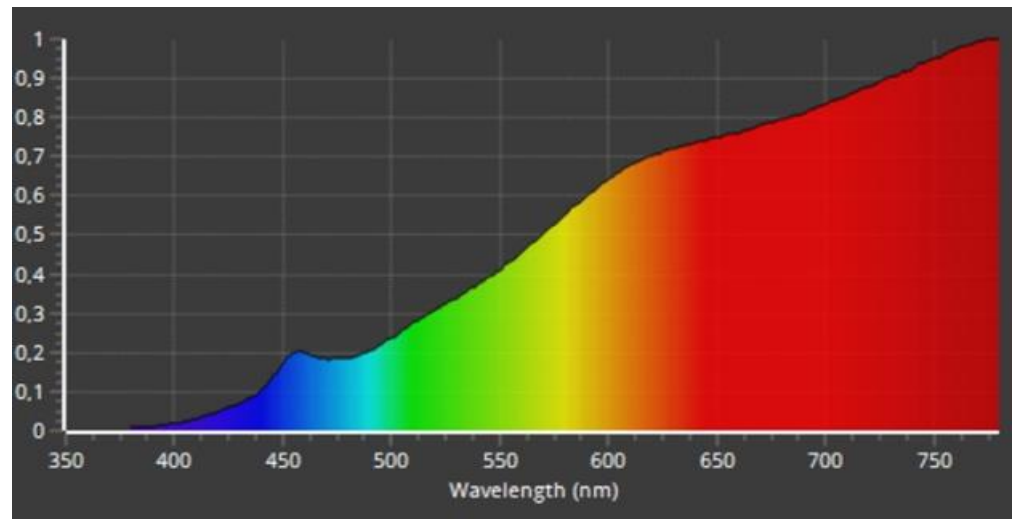

Рис. 3. Спектр освітлювальної установки зі світлодіодними світильниками для загального освітлення та світильниками з ГЛР для місиевого освітлення

Із отриманих результатів видно, що таким шляхом можна досягти виконання умов «меланопсинового хреста». При цьому можна також значно підвищити загальний індекс кольоропередавання Ra. Недоліком такого технічного рішення $\epsilon$ те, що ефективність освітлювальних установок знижується до 40 - 45 лм/Вт, так як світлова віддача ГЛР значно нижча за світлову віддачу світлодіодних джерел світла. Але результуюча світлова ефективність світильників зі світлодіодами та ГЛР не набагато нижча від дослідних зразків нових світлодіодів, що застосовуються в лампах Soraa PAR38 (див. табл. 1).

Іншим шляхом покращення спектрального розподілу випромінення в області 450 нм 480 нм $є$ застосування в світильниках селективних фільтрів для обмеження рівня випромінення при довжині хвилі 450 нм і збільшити його в області 480 нм, де має місце «провал». Для дослідження ми використовували стандартні жовті фільтри ЖС 3, ЖС4, ЖС10, ЖС11, ЖС12. Спектри пропускання цих фільтрів наведені на рис. 4. В якості відбиваючих матеріалів використовували зразок фарби з коефіцієнтами відбиття, наведеними на рис. 5.

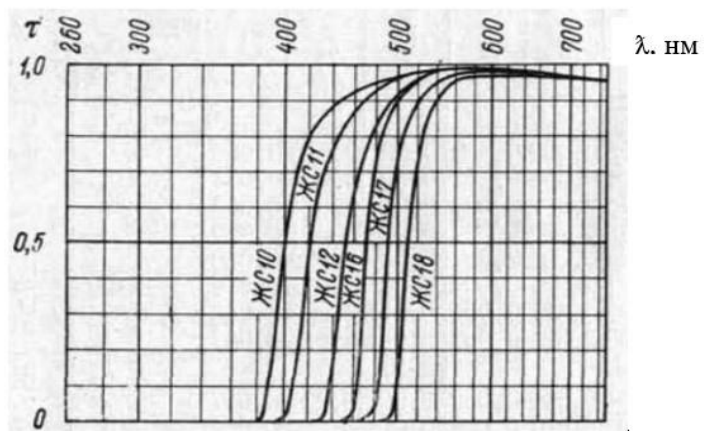

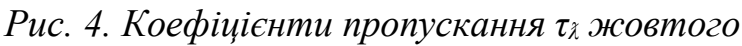
скла товщиною 5 мм

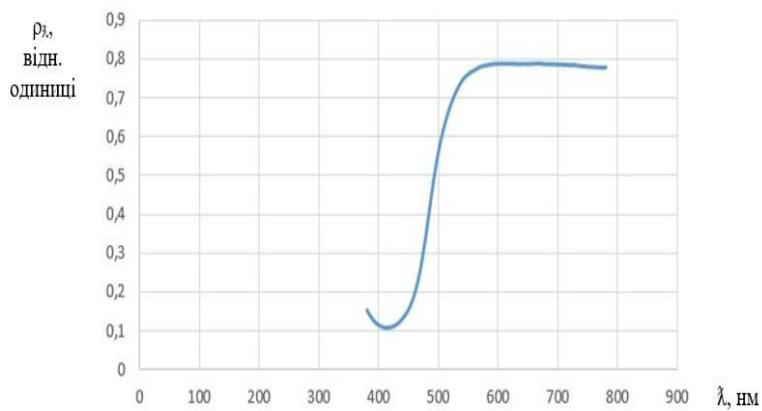

Рис. 5. Коефіиієнт відбиття $\rho$ ґразка жовтої фарби

В таблиці 3 та на рис.6 і рис.7 наведені результати вимірювання світлотехнічних та спектральних характеристик світлодіодних світильників 3 використанням цих матеріалів. Застосування фільтрів, що обмежують випромінення синього світла дозволяє більш ефективно коригувати спектр світлодіодного світильника для досягнення умов «меланопсинового хреста» в порівнянні з використанням ГЛР, але при цьому знижується якість кольоропередавання. Ми вибирали фільтр таким чином, щоб загальний індекс кольоропередавання $\mathrm{R}_{\mathrm{a}}$ не знижувався менше 80. 


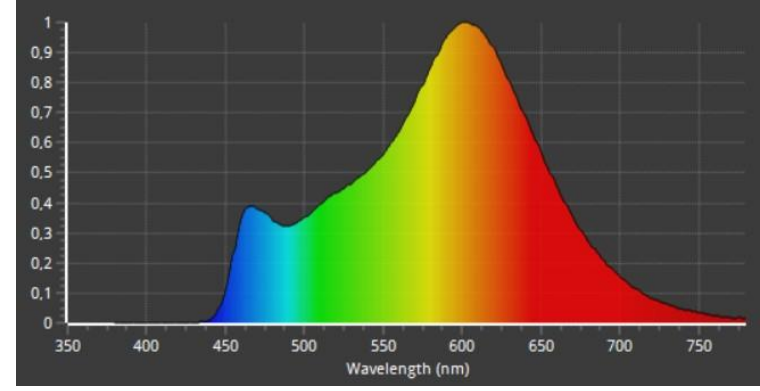

Рис. 6. Спектр світлодіодного світильника з ССТ $2950 \mathrm{~K}$ з відбиваючою білою емаллю та корегуючим світлофільтром із жовтого скла ЖС12

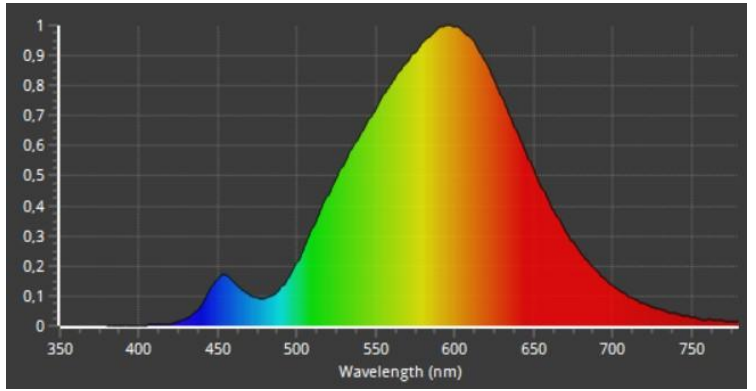

Рис. 7. Спектр світлодіодного світильника з ССТ 2950 К (з відбиваючою жовтою емаллю та жовтим фільтром ЖС12)

Таблиця 3. Результати вимірювання параметрів світильників 3 використанням фільтрів із жовтого скла та відбиваючих екранів з білої та жовтої фарби

\begin{tabular}{|c|c|c|c|c|c|c|c|}
\hline 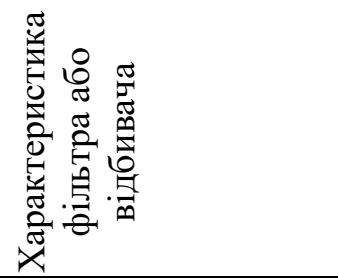 & 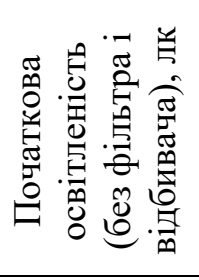 & 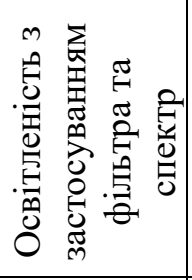 & $\begin{array}{l}\mathscr{U} \\
\tilde{U}\end{array}$ & జ & 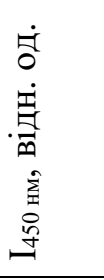 & 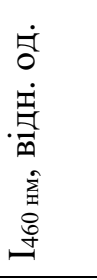 & 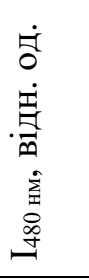 \\
\hline ЖС11, біла фарба & 329 & 245 & 2971 & 82,8 & 1,09 & 2,21 & 1,84 \\
\hline ЖС12, біла фарба & 329 & 257 & 2905 & 81,6 & 0,59 & 1,87 & 1,86 \\
\hline ЖС16, біла фарба & 329 & 232 & 2820 & 79,5 & 0,14 & 0,86 & 1,56 \\
\hline ЖС11, жовта фарба & 329 & 329 & 2977 & 84,1 & 1,71 & 3,24 & 2,53 \\
\hline ЖС12, жовта фарба & 329 & 301 & 2865 & 81,6 & 1,39 & 2,71 & 2,19 \\
\hline ЖС16, жовта фарба & 329 & 307 & 2845 & 80,7 & 1,17 & 2,30 & 1,92 \\
\hline
\end{tabular}

Застосування селективних відбиваючих матеріалів в світильниках також дозволяє змінювати спектральний склад випромінення і, за певних умов, разом з застосуванням фільтрів, що обмежують випромінення синього світла, можуть використовуватись для підвищення фотобіологічної безпечності світлодіодних світильників. Для покращення світло-колірного середовища, що створюють світлодіодні освітлювальні установки, можна також використовувати селективне відбивання стін та стелі приміщення.

Висновки. Світильники та світлодіодні лампи на основі світлодіодів, кристали яких випромінюють синє світло, що частково перетворюється за допомогою люмінофору в жовтооранжеве мають надлишок синього випромінення відносно рівня при довжині хвилі 480 нм. Для підвищення фотобіологічної безпеки світлодіодних ламп та світильників необхідно значно знижувати рівень випромінення на ділянці спектру 3 довжиною хвиль $400-450$ нм і збільшувати в області з максимумом при 480 нм.

Для зниження фотобіологічної небезпеки синього світла при освітленні житлових приміщень, дитячих та навчальних закладів необхідно застосовувати світлодіодні лампи та світильники з ССТ не вищою за 3500 К, які створюють не суттєву надлишкову дозу синього світла і є більш безпечні, ніж світильники з високими ССТ.

Розроблені технічні рішення щодо коригування спектрального складу випромінення освітлювальних установок шляхом спільного застосування світлодіодних ламп (світильників) та галогенних ламп розжарювання. При цьому для досягнення умов «меланопсинового хреста» ССТ світлодіодних ламп має не перевищувати $3500 \mathrm{~K}$, а рівень освітленості, що створює ГЛР має бути не нижчий рівня, утвореного світлодіодними джерелами світла. Світлова ефективність при цьому знижується приблизно на 40 \%, а індекс кольоропередавання зростає до 95 одиниць

3 метою зменшення рівня випромінення в області спектру з максимумом при 450 нм та підвищення рівня випромінення в області з максимумом при 480 нм, що може забезпечити 
виконання умов «меланопсинового хреста» для світлодіодних світильників з ССТ до $3500 \mathrm{~K}$ та $\mathrm{R}_{\mathrm{a}} \geq 80$, запропонована технологія коригування спектру шляхом застосування фільтрів 3 мінімальним коефіцієнтом пропускання при 450 нм і максимальним коефіцієнтом в інтервалі довжин хвиль 460 - 760 нм та відбиваючих світло матеріалів 3 мінімальним коефіцієнтом відбиття при 450 нм та максимальним в інтервалі 460 - 760 нм.

\section{ЛIТЕРАТУРА}

1. Sliney D.H. Blue-light injury can result from viewing either extremely light for a short time or less bright light for a longer time // Oculor Injury to Light Toxicity. International Ophthalmology Clinics. - 1998/ Vol. 28, №3. - P. 246-250.

2. Островский М.А. Молекулярные механизмы повреждающего действия света на структуры глаза и системы защиты от такого повреждения / М. Островский // Успехи биологической химии. - 2005. T. 45. - C. 173-204.

3. Закгейм А.Л. Светодиодные системы освещения: энергоэффективность, зрительное восприятие, безопасность для здоровья (обзор) / А.Л. Закгейм // Светотехника. - 2012. - №2. - С. 12-21.

4. Зак П.П. Потенциальная опасность освещения светодиодами для глаз детей и подростков / Зак П., Островский М. // Светотехника. - 2012. - №3. - С.4-7.

5. Слайни Д.Х. Влияние новых светотехнических приборов на здоровье и безопасность людей / Д.Х. Слайни // Светотехника. - 2010. - №3. - С. 49-50.

6. Капцов В.А., Дейнего В.Н. Синий свет светодиодов - новая гигиеническая проблема / В.А. Капцов, В.Н. Дейнего // Анализ риска здоровью. - 2016. - №1(13). - С. 15-25.

7. CIE TN 002:2014 Technical Note: Relating Photochemical and Photobiological Quantities to Photometric Quantities. Vienna. - 2014. - 4 p.

8. ICINIRP Guidelines on Limits of Exposure to Incoherent Visible and Infrared Radiation Published in: Health Physics. 2013, №105(1), 74-95 p.

9. IEC/TR 62471:2006/CIE S 009:2002 Photobiological safety of lamps and lamp systems (bilingual edition).

10. Sliney D.H. Blue light risk and light therapy. US Army Center for Health Promotion and Preventive Medicine Aberdeen Proving Ground, MD, USA Available at: http://citeseerx.ist.psu.edu/viewdoc/download?doi=10.1.1.548.4019\&rep=1\&type=pdf (11.10.2015).

11. CTLMA-ELEC LED WG (SM) 011_ELC CELMA position paper optical safety LED lighting. Juli, 2011.

12. Дейнего В.Н., Капцов В.А. Свет энергосберегающих и светодиодных ламп и здоровье человека / В.Н. Дейнего, В.А. Капцов // Гигиена и санитария. - 2013. - № 6. - С. 81-84.

13. Капцов В.А. Изменения и концентрация построения светодиодов для освещения с учетом здоровья человека / В.А. Капцов, В.Н. Дейнего // Энергосвет: электронный журнал. - 2015. - № 4 (41). - С. 40-44.

14. EN 13032-4:2015 Light and lighting. Measurement and presentation of photometric data of lamps and luminaires LED lamps, modules and luminaires. 